\title{
Do 'largão' da terra 'voluta' à estreiteza da terra vendida: reflexões sobre territórios e comunidades quilombolas no norte de Mato Grosso do Sul
}

\author{
From vast public lands to the narrowness of sold land: reflections on quilombola \\ territories and communities in northern Mato Grosso do Sul
}

\author{
Jorge Eremites de Oliveiral (1) | Levi Marques Pereira" \\ Universidade Federal de Pelotas. Pelotas, Rio Grande do Sul, Brasil \\ "Universidade Federal da Grande Dourados. Dourados, Mato Grosso do Sul, Brasil
}

\begin{abstract}
Resumo: Neste artigo, os autores analisam as transformações ocorridas nas formas de acesso à terra por diferentes segmentos da sociedade nacional no norte do estado brasileiro de Mato Grosso do Sul. A discussão é realizada em torno do caso da comunidade quilombola Família Bispo, localizada no município de Sonora, região historicamente vinculada a uma área fronteiriça entre os territórios dos povos indígenas Bororo e Kayapó. O caso analisado é emblemático porque abrange indígenas, quilombolas e migrantes de outros estados da federação, todos envolvidos por relações de alianças e disputas, as quais têm como foco principal a posse e a propriedade da terra. A transformação do espaço, com anuência e participação de agentes do Estado nacional, resultou, segundo a expressão de um interlocutor, na expropriaçãa dos territórios indígenas e quilombolas, pois o 'largão' da terra 'voluta' [devoluta] foi transformado em terra vendida, propriedade privada, regularizada com contratos e escrituras cartoriais.
\end{abstract}

Palavras-chave: Comunidades quilombolas. História de Mato Grosso do Sul. Município de Sonora. Povos indígenas Bororo e Kayapó. Territorialização.

Abstract: In this article the authors analyze transformations in the forms of land access among different segments of society in the north of the Brazilian state of Mato Grosso do Sul. The discussion focuses on the Família Bispo quilombola community in the municipality of Sonora, a region historically linked to a border area between the Bororo and Kayapó indigenous peoples. The case analyzed is emblematic because it includes indigenous people, quilombolas, and migrants from other Brazilian states, all involved in alliances and disputes mainly surrounding land tenure and ownership. The transformation of space with the consent and participation of government agents, resulted (as one interlocutor stated) in the expropriation of indigenous and quilombola territories, because the vast public lands were transformed into land that was sold and privately owned, regularized through contracts and notary deeds.

Keywords: Quilombola communities. History of Mato Grosso do Sul. Municipality of Sonora. Bororo and Kayapó Indigenous Peoples. Territorialization.

Eremites de Oliveira, J., \& Pereira, L. M. (2020). Do 'largão' da terra 'voluta' à estreiteza da terra vendida: reflexões sobre territórios e comunidades quilombolas no norte de Mato Grosso do Sul. Boletim do Museu Paraense Emílio Goeldi. Ciências Humanas, 15(3), e20200016. doi: 10.1590/2178-2547-BGOELDI-2020-0016

Autor para correspondência: Jorge Eremites de Oliveira. Universidade Federal de Pelotas. Departamento de Antropologia e Arqueologia. Instituto de Ciências Humanas. Rua Alberto Rosa, 154. Pelotas, RS, Brasil. CEP 96010-770 (eremites@hotmail.com).

Recebido em 14/02/2020

Aprovado em 15/04/2020

Responsabilidade editorial: Márcio Couto 
Diga você me conhece / Eu já fui boiadeiro / Conheço essas trilhas / Quilômetros, milhas / Que vêm e que vão / Pelo alto sertão / Que agora se chama / Não mais de sertão / Mas de terra vendida / Civilização [...] / Tempos e vidas cumpridas / Pó, poeira, estrada / Estórias contidas / Nas encruzilhadas / Em noites perdidas / No meio do mundo / Mundão cabeludo / Onde tudo é floresta / E campina silvestre / Mundão "caba" não (Sater \& Teixeira, 1982).

Entre 2003 e 2012, realizamos - por meio de uma profícua parceria profissional e a partir da concatenação (in)disciplinada de procedimentos científicos recorrentes nos campos da antropologia social, arqueologia, história e outros - diversos trabalhos no Centro-Oeste do Brasil. A maioria dos estudos incide sobre a temática dos territórios de comunidades indígenas e quilombolas em Mato Grosso do Sul, embora tenhamos concluído pesquisas pontuais de interesse ao assunto em Mato Grosso e no Distrito Federal. Esta prática conjunta está relacionada a demandas voltadas à produção de laudos administrativos e judiciais sobre terras tradicionalmente ocupadas, realização de pesquisas acadêmicas e participação na (re)elaboração de relatórios socioambientais a respeito de empreendimentos que afetam a dinâmica da vida em sociedade, entre outras ações. Compreende estudos, vivências, interlocuções vis-à-vis com o Outro, reflexões descolonizantes e a circulação por milhares de quilômetros no Brasil profundo, onde muitos trabalhos de campo são concluídos em ambientes colonialistas (Souza et al., 2012; Eremites de Oliveira, 2012a, 2012b, 2013, 2015, 2017a, 2017b; Eremites de Oliveira \& Pereira, 2007, 2009, 2010, 2012; Pereira, 2003, 2006, 2009, 2010, 2016, 2018; Pereira \& Ximenes, 2017).

A expressão 'Brasil profundo', empregada por Eremites de Oliveira (2016), Oliveira (2002) e outros autores, que também lembra a ideia de 'México profundo', de Bonfil Batalla (1989), diz respeito às extensões do território nacional que estão distantes da realidade dos grandes centros metropolitanos e, portanto, com pouca ou nenhuma visibilidade perante a maioria da população nacional. Este termo é aqui empregado a partir de sua concatenação com a ideia de 'ambientes colonialistas', isto é, os cenários marcados "por várias formas de violência e tentativas de dominação contra minorias étnicas, sitiadas e constrangidas por diversos mecanismos de sujeição", os quais estão estruturados "por um conjunto de relações sociais e de poder, linguagens, práticas e saberes que marcam a relação do Estado e de amplos segmentos da sociedade nacional para com [esses coletivos]" (Eremites de Oliveira \& Pereira, 2010, pp. 190-191).

Em contextos deste tipo, as comunidades indígenas e quilombolas costumam estar mobilizadas e, desta maneira, colaboram ativamente para o bom andamento dos trabalhos de campo. Às vezes, porém, especialmente quando se trata da produção de laudos administrativos e judiciais a envolver o litígio pela posse de terras, faz-se necessário solicitar apoio policial para assegurar in loco a realização das pesquisas. Significa dizer que a prática etnográfica nessas áreas está revestida de grande complexidade, pois foge à rotina acadêmica tida como intramuros e, ademais, prescinde a expertises já discutidas em outros trabalhos de nossa autoria, citados anteriormente.

Toda esta experiência de base etnográfica possibilitou compreender in loco que o território de uma comunidade tradicional é o espaço sociocultural multidimensional da (re)produção humana por excelência, o que se dá através da interação entre diversos atores sociais nos ambientes de vida em que estão inseridos. No caso da produção do território de comunidades remanescentes dos quilombos, as mesmas costumam ressaltar - em observação à legislação nacional - sua capacidade "de constituir um território autônomo e demarcá-lo simbólica e geograficamente" (Fiabani, 2005, p. 367). Esta competência pressupõe uma relação 'orgânica' entre os seres humanos com o chão, a terra, o suporte material de suas vidas, isto é, com o território enquanto espaço produzido, apropriado, sentido, usado, marcado, experimentado e vivenciado. 
Logo, compreender a produção (e a reprodução) desse território requer a apreensão das dimensões políticas, simbólicas e materiais que permeiam as relações dos coletivos com os lugares tradicionalmente ocupados.

Em muitos casos, parte da materialidade da realidade territorial pode ser observada sincrônica e diacronicamente no espaço físico, especialmente em elementos da cultura material, paisagens humanizadas, sistemas de assentamentos ligados a formas organizacionais, cemitérios, locais de valor simbólico registrados na memória das pessoas etc. Esta constatação, contudo, embora baseada em estudos (etno)arqueológicos, não significa que seja fácil traçar linhas precisas no espaço sociocultural, cujo tamanho varia no tempo, a depender das relações sociais que nele são desenvolvidas. Não obstante a esta ideia, cumpre explicar que, nos estudos produzidos para a identificação e delimitação de terras tradicionalmente ocupadas, a materialidade contribui para as próprias comunidades melhor perceberem seus territórios, avivarem memórias individuais e coletivas e indicarem o tamanho da área a ser reivindicada (Eremites de Oliveira \& Pereira, 2007, 2009, 2010, 2012).

No âmbito das ciências sociais lato sensu, normalmente, o termo territorialidade é recorrido para se referir ao modo como uma população (re)produz seu território e a si mesma no tempo e espaço, como verificado em várias publicações no Brasil (Martins, 1997; O'Dwyer, 2002, 2008; Haesbaert, 2006; Valencio, 2009, e outros). Por isso mesmo, a territorialidade está longe de ser algo dado a priori como absoluto, imóvel, estático ou mero receptáculo de ações alhures, como se pudesse ser natural, neutro, fossilizado e a-histórico. Segundo M. Santos (2002, 2004), o espaço pode ser entendido como a acumulação desigual de tempos. Esta afirmativa possibilita deduzir que em determinados períodos as populações tradicionais competem/negociam na produção do próprio espaço. Exemplo da situação está na denominação e humanização de elementos das paisagens (morros, rios, lagoas, córregos, caminhos, locais de moradia etc.) e no usufruto e manejo de nichos ecológicos.
No caso da Família Bispo, localizada no município de Sonora, extremo norte do estado de Mato Grosso do Sul, na divisa com o Mato Grosso, a comunidade quilombola continua a existir, resistir e a produzir sua territorialidade em atenção a formas particulares de tradicionalidade. Estas práticas têm sofrido impactos negativos, claro, devido a restrições impostas pelo Estado e por outros atores com os quais disputam e negociam a produção do espaço. Resulta daí o que pode ser reconhecido como um caso de territorialidade precária, entendida como territorialidade instável, insegura e suscetível a reveses, haja vista o fato da área ainda não ter sido regularizada. Este conceito está inspirado no estudo de Mota (2011), ressalvadas as devidas diferenças históricas e socioculturais de suas reflexões em relação ao caso em epígrafe.

Na referida região, a expropriação territorial, embora intensa e violenta, ocorrida principalmente desde a primeira metade do século $X X$, não demoveu totalmente a percepção da comunidade em relação à reivindicação de posse da terra. Esta consciência segue viva na mente das pessoas, faz parte de uma memória social e produz efeitos, relações e significações, mesmo em um contexto extremamente adverso, tenso e conflituoso. Parte da comunidade ali permanece e está estabelecida em uma pequena porção de seu antigo território.

Neste sentido, importa explicar que as atividades de pesquisa que embasam este trabalho foram desenvolvidas em 2008 junto a famílias que compõem a comunidade, viabilizadas por meio de um convênio firmado entre o Instituto Nacional de Colonização e Reforma Agrária (INCRA) e a Universidade Federal da Grande Dourados (UFGD), doravante citado como Convênio INCRA/UFGD. O objetivo do convênio interinstitucional foi o de realizar estudos de campo, bibliográfico e documental para a elaboração de relatórios de caracterização histórica, econômica e sociocultural de territórios quilombolas no estado, com o propósito de viabilizar sua regularização fundiária. 
O relatório produzido sobre a área da comunidade Família Bispo apresenta, de forma sucinta, o material levantado durante as pesquisas de campo e as dificuldades e impasses que impediram a finalização do relatório técnico. Serviu de base para a elaboração do presente estudo. Além disso, cumpre ressaltar que, desde aquele ano até o tempo presente, temos acompanhado, à distância, os encaminhamentos dados pela comunidade frente à questão fundiária.

No sítio eletrônico do Ministério Público Federal (MPF), consta, na data de 15/11/2019, a listagem de 18 comunidades quilombolas para o estado de Mato Grosso do Sul, as quais possuem procedimento administrativo junto ao INCRA, incluindo a da Família Bispo, além de outras quatro sem procedimento administrativo junto ao órgão, todas elas certificadas pela Fundação Palmares (MPF, n.d.)'.

\section{OFICINA DE CAPACITAÇÃO E PLANEJAMENTO}

Em julho de 2008, foi realizada nas dependências da UFGD, no antigo Centro Universitário de Dourados (CEUD), a primeira atividade do Convênio INCRA/ UFGD: uma oficina de capacitação e planejamento para os trabalhos de campo. Reuniram-se técnicos e pesquisadores das duas instituições, lideranças quilombolas cujas terras seriam objeto de estudos para fins de regularização e também membros do movimento negro e quilombola no estado. A oficina contou com a assessoria de experientes pesquisadores (como o antropólogo José Maurício P. A. Arruti), que têm se dedicado a estudar temas relacionados às populações afrodescendentes e à elaboração de relatórios para a regularização fundiária de terras quilombolas ${ }^{2}$. A atividade foi fundamental para socializar alguns procedimentos metodológicos e promover o conhecimento recíproco entre as lideranças das comunidades e os técnicos e pesquisadores envolvidos nos trabalhos.

$\mathrm{Na}$ ocasião, foi possível identificar que as lideranças de algumas comunidades reconheciam e verbalizavam que suas famílias vivenciavam processos de (re)descoberta (jurídica) da identidade grupal. Esta experiência ocorre por conta do modo como é legalmente estabelecida a condição de quilombola no Brasil, especialmente a partir da Carta Constitucional de 1988, embora há muito desenvolvessem relações de parentesco e práticas políticas e religiosas que configuram relações comunitárias. Explicaram que começavam a perceber que suas famílias compunham grupos baseados no parentesco e outras formas de organização sociopolítica. Emergia, assim, a percepção mais formalizada da configuração das famílias enquanto grupo social e sujeito coletivo. Nas discussões, gradativamente apareceram, para cada comunidade, elementos da experiência histórica comum de territorialização em um espaço específico, intrinsecamente associado à sua memória social. Como os territórios tinham sido total ou parcialmente perdidos em termos jurídicos, surgia o desejo de reavê-los para neles recomporem os coletivos e atualizarem as figurações sociais que existiam antes do processo de expropriação da terra.

Os representantes ali presentes relataram, de forma resumida, as histórias de suas famílias e enfatizaram que o processo de perda da terra dispersou diversos membros das comunidades. As narrativas giraram em torno do processo de desterritorialização ou remoção forçada dos grupos, especificamente sobre como perderam as terras para representantes das frentes de expansão agropecuária ou, no caso da comunidade urbana de Tia Eva, em Campo Grande, para a expansão do perímetro urbano da capital do estado.

\footnotetext{
Sobre o assunto, ver, por exemplo, Aguilera Urquiza e Santos (2017), Baldo (2015), C. Santos (2010) e Saruwatari (2014).

2 Ver, por exemplo, Arruti (2006).
}

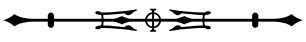


A situação histórica apontada dificultou a realização de uma série de eventos comunitários, como as práticas de casamento intragrupais, os mutirões para realização de atividades produtivas e, ainda, a cooperação e a participação conjunta em festas e rituais religiosos. A dificuldade para a realização de tais práticas, fundamentais à reprodução física e cultural dos coletivos enquanto comunidades, aos poucos solapou certos vínculos societários. Trata-se de uma realidade associada à fragmentação dos grupos e à diminuição da capacidade de se apresentarem como sujeitos coletivos.

A perda do território ou, em alguns casos, do controle da totalidade da área onde as famílias desenvolviam sua experiência sociocultural foi um forte fator de desagregação das populações locais. Soma-se a isso a 'modernização' da sociedade nacional, ocorrida nas últimas décadas, que exerceu e segue a exercer influências nas comunidades quilombolas, pois costuma estimular a adoção de novos estilos de conduta e promover outras mudanças. Tais estilos propugnam a difusão de valores ligados à individualidade e, via de regra, desestimulam as práticas de associação coletiva, baseadas em relações de compadrio, vizinhança, parentesco, reconhecimento de liderança política ou religiosa etc.

A partir do processo de redemocratização do país, oficializado com a promulgação da Constituição Federal em 5 de outubro de 1988, houve a criação gradual de um ambiente favorável para que as populações quilombolas se (re)organizassem em entidades e passassem a reivindicar seus direitos. No contexto de Mato Grosso do Sul, ocorre um processo gradual de autopercepção de famílias negras enquanto comunidades quilombolas, especificamente nos casos em que há profundidade histórica na ocupação de determinadas áreas e a identidade com um espaço específico.

Em linhas gerais, dessa maneira, as famílias adquirem visibilidade e expressão política enquanto sujeitos coletivos. Podem ser consideradas como emergentes ou reemergentes, fenômeno este verificado a partir de reconexões com formas sociais vivenciadas mais intensamente no passado. Antes não podiam dar visibilidade a seu ser coletivo, mas, a partir do momento em que o estatuto jurídico e as condições políticas conferem esta abertura, começam a reivindicar e a exercer abertamente os direitos constitucionais. A situação indicada causa estranhamento a setores da sociedade nacional, especialmente entre os proprietários de terras rurais e suas entidades de associação, que passam a ver nos novos sujeitos uma ameaça a seus direitos territoriais.

Além disso, as lideranças das comunidades quilombolas reunidas na mencionada oficina reivindicaram que o trabalho de identificação e delimitação dos territórios deveria propiciar o encontro das famílias. Destacaram ser necessário reencontrar pessoas que vivem em diversos municípios sul-matogrossenses ou mesmo em outros estados da federação. Foram enfáticos na apresentação da necessidade de os pesquisadores reunirem as pessoas antigas, dado que apenas elas poderiam detalhar com precisão a história de cada comunidade e, assim, recompor sua trajetória e historicidade.

No Quadro 1, há a exposição que os membros da Família Bispo realizaram naquele momento, assim sintetizada pela secretaria do evento. A dinâmica adotada na ocasião foi conduzida por José Maurício P. A. Arruti, que traçou o balizamento metodológico com vistas a nortear as pesquisas de campo. A oficina foi realizada por meio de uma construção colaborativa, de forma a reunir contribuições que emergiram entre os membros das famílias quilombolas, pesquisadores da UFGD e funcionários do INCRA.

Diante do Quadro 1, nota-se que a oficina viabilizada pelo Convênio INCRA/UFGD produziu as primeiras informações sistematizadas textualmente sobre a situação histórica da comunidade Família Bispo. Este procedimento foi de grande utilidade para o planejamento dos trabalhos de campo. 
Quadro 1. Narrativas históricas sobre a comunidade quilombola Família Bispo.

\begin{tabular}{|c|c|}
\hline \multicolumn{2}{|r|}{ Comunidade Quilombola Família Bispo (Sonora, Mato Grosso do Sul) } \\
\hline Formação histórica (origem) & $\begin{array}{l}\text { Nascida no 'Pantanal', a comunidade é formada por um conjunto de famílias ribeirinhas. As } \\
\text { terras foram herdadas da avó Eugênia. A comunidade tem seus próprios cemitérios. Até } \\
\text { poucas décadas atrás, dispunham de } 500 \text { hectares, cujo espaço foi reduzido para apenas } 120 \\
\text { hectares. Os proprietários vizinhos cercam suas áreas e entram nas terras das comunidades. } \\
\text { Obs.: posteriormente, o trabalho de campo realizado por pesquisadores da UFGD revelou que } \\
\text { a área de ocupação tradicional era, de fato, muito maior do que a área que conseguiram legalizar } \\
\text { em nome do líder da comunidade. Isto ocorreu quando as terras da região eram disputadas por } \\
\text { particulares que ali chegavam em busca de terras públicas, então consideradas devolutas. }\end{array}$ \\
\hline $\begin{array}{l}\text { Formas de uso da terra } \\
\qquad(\text { ontem e hoje) }\end{array}$ & $\begin{array}{l}\text { Pesca e turismo são as principais atividades no tempo presente. No passado, havia uma escola } \\
\text { rural na região. Plantavam arroz e feijão em várias áreas e para além dos } 500 \text { hectares. } \\
\text { Na infância dos adultos de hoje, a comunidade foi vista como diferente, pelo fato de todos os } \\
\text { seus membros serem de uma única grande família, composta por pessoas negras. Hoje, já não } \\
\text { pescam e trabalham como empregados dos empreendimentos ligados ao turismo. Bebem a } \\
\text { água do rio Correntes, que divide os estados de Mato Grosso e Mato Grosso do Sul, a qual } \\
\text { estaria contaminada pelo despejo de esgoto e outras formas de poluição. }\end{array}$ \\
\hline $\begin{array}{l}\text { Expropriação ou conflitos } \\
\text { (históricos e atuais) }\end{array}$ & $\begin{array}{l}\text { Um pedaço de terra foi cedido pelo avô para um compadre (onde havia a maioria das roças). } \\
\text { Antes da filha de Eugênia, chamada Josefa, falecer, houve uma divisão: seis pessoas resolveram } \\
\text { vender a terra e outras seis pessoas resolveram ficar na área. Estas últimas são as que ocupam } \\
\text { a terra hoje em dia. Um advogado teria conseguido uma procuração de Josefa para que } \\
\text { pudesse vender tais terras; daí veio a divisão entre os doze irmãos e a venda de metade da } \\
\text { área deles. Todavia, segundo entendem, todos os documentos mantêm-se como de compra } \\
\text { e venda; ninguém, de dentro ou de fora, teria títulos legítimos. Consideram que a polícia } \\
\text { reprime os moradores da comunidade em resposta às suas queixas diretas aos proprietários } \\
\text { vizinhos. Também disseram que uma proprietária lindeira 'comeu' parte das terras e colocou } \\
\text { fogo na mata ao lado da casa da sua mãe, Josefa, de } 80 \text { anos; também fez o represamento do } \\
\text { rio a ponto de a água subir e inundar a área de roça da comunidade. O mesmo aconteceu } \\
\text { com um córrego que passa fora da comunidade. Também alegaram que alguns desses } \\
\text { proprietários vizinhos seriam matadores profissionais, ligados a um antigo prefeito da cidade. } \\
\text { Disso resultam ameaças à comunidade e, em especial, a duas ou três pessoas que dali saem } \\
\text { com mais frequência para participar de reuniões, eventos etc., assim o fazendo em nome da } \\
\text { associação quilombola. Os proprietários vizinhos constroem tanques de piscicultura e não } \\
\text { são reprimidos, mas quando um dos moradores da comunidade fez o mesmo, foi reprimido } \\
\text { pela Secretaria Estadual de Meio Ambiente (SEMA) em } \mathrm{R} \$ 30.000,00 \text { (trinta mil reais). Josefa, } \\
\text { a antiga líder da comunidade, requereu } 275 \text { hectares, que se desdobra nas pequenas frações } \\
\text { ainda em posse de seus descendentes. }\end{array}$ \\
\hline Usos concorrentes atuais & $\begin{array}{l}\text { Hoje, as terras vendidas estão sendo usadas como pousadas e empreendimentos pesqueiros, } \\
\text { e parte dos antigos donos (membros da comunidade quilombola) virou empregada desses } \\
\text { locais. Atualmente, há uma barragem na área, que acabou com os peixes do rio, o qual } \\
\text { está assoreado a ponto de ter um campo de futebol no meio de seu leito. Logo depois da } \\
\text { construção da barragem de uma hidrelétrica, o rio teria secado completamente por mais de } \\
\text { um mês. Junto com isso, houve muito desmatamento por parte dos fazendeiros vizinhos. } \\
\text { A comunidade procurou o Instituto Brasileiro do Meio Ambiente e dos Recursos Naturais } \\
\text { Renováveis (IBAMA) para reclamar, mas não teve o retorno dos 'florestais'. Há muitos } \\
\text { problemas ambientais no entorno que se refletem na comunidade. }\end{array}$ \\
\hline $\begin{array}{l}\text { Formas de organização interna } \\
\text { (grupos tradicionais, sindicato, } \\
\text { associações [estatuto quilombola?]) }\end{array}$ & $\begin{array}{l}\text { Realizam a festa de São Sebastião (19 de janeiro). Em 2008, a associação da comunidade } \\
\text { estava legalizada há três anos. }\end{array}$ \\
\hline
\end{tabular}

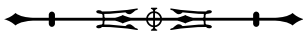


Comunidade Quilombola Família Bispo (Sonora, Mato Grosso do Sul)

Processo de reconhecimento (como conheceram a questão quilombola, quem mediou, qual o nível de reconhecimento público local)

Processo de identificação (como foi a discussão interna, unidade do grupo em torno da demanda, parentes de fora retornando)
Começaram a discutir o assunto depois da visita de Borjinho e Zezão, lideranças do movimento negro e quilombola do estado. Receberam alguns poucos benefícios depois do reconhecimento, por meio da Coordenação das Comunidades Negras Rurais Quilombolas de Mato Grosso do Sul (CONERQ/MS). Na época da pesquisa, a situação era bem precária para as famílias que viviam na terra, com grande vulnerabilidade a constantes ameaças.

grupo caminha na direção da identificação, mas ainda não há unidade no coletivo. Há conflitos entre os descendentes, principalmente entre os que venderam e os que ficaram na terra. $\bigcirc$ grupo que saiu não aceita que as terras vendidas retornem à comunidade. A demanda das terras é justamente da totalidade dos lotes dos seis filhos de Josefa e mais o lote do irmão dela. Há dúvida sobre o caráter formal dos documentos que os seis herdeiros que restaram dizem possuir sobre a área. Também há dúvida sobre como fazer depois com a titulação, precisamente no que se refere à necessidade de abrir mão da propriedade privada para uma propriedade coletiva, em nome da associação da família.

Obs.: a pesquisa de campo revelou que existem problemas quanto à definição de quais famílias fariam parte da comunidade atual, denominada de Família Bispo. Verificou-se que, embora um grande número de famílias tenha um histórico de pertencimento ao espaço onde a comunidade tradicionalmente viveu, muitas famílias encontram dificuldade de se incluir na comunidade política, haja vista os atritos intensificados no processo de expropriação do território.

\section{CARACTERIZAÇÃO HISTÓRICA E ANTROPOLÓGICA DA COMUNIDADE}

A presente caracterização histórica e antropológica da comunidade Família Bispo está baseada no levantamento de fontes escritas e, principalmente, em pesquisas de campo, realizadas ao tempo do convênio interinstitucional. O relatório de pesquisa apresentado ao INCRA inclui a leitura crítica da Nota Técnica elaborada pelo analista em antropologia do MPF em Dourados, M. Lima (2007), e de peças processuais elaboradas por técnicos do instituto.

Na pesquisa que realizamos em agosto de 2008, logo de início foi detectado que a principal referência geográfica da comunidade é o antigo cruzamento da rede de telégrafo do rio Correntes, agora desativado, localizado na margem direita do curso d'água e denominado de Porto Correntes. Na localidade, existia um porto de ancoradouro para pequenas embarcações nas duas margens do rio, onde era frequente o trânsito de pessoas e bens. $\bigcirc$ embarcadouro fazia do local um espaço de conexão entre grupos de famílias que por ali transitavam. Tudo indica que, desde as primeiras décadas do século $X X$, o porto não era local ermo e isolado, pelo contrário. Configurava-se como uma conexão de fluxos de famílias negras e indígenas (principalmente Bororo) que viviam na região, além de outros ocupantes que passaram a circular pela área com a intenção de regularizar terras no antigo estado de Mato Grosso, do qual foi criado, em 1977, o estado de Mato Grosso do Sul. No local, atualmente, o rio Correntes é tomado como limite geográfico entre os dois estados.

Foi justamente no porto da margem esquerda do rio Correntes que Manoel Bispo construiu sua casa. Naquela área, ele viveu grande parte de sua vida, juntamente com sua esposa, Josefa Bispo, onde criaram a família e praticavam atividades produtivas (pequenas roças, criação de animais e pesca, entre outras). Nas últimas décadas, quando Sonora entrou para o mapa do turismo de pesca, o chefe da família atuou como guia de turistas, dado o conhecimento que detinha sobre a hidrografia local e seus recursos pesqueiros. Este ofício segue praticado por alguns de seus filhos. A atividade de pesca turística chega à região quando as famílias que compõem a comunidade perderam o domínio sobre o território que antes ocupavam.

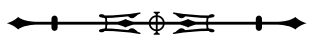


Os dados levantados em campo permitem afirmar que a presença de famílias da comunidade Família Bispo é muito antiga na região. Joel Bispo, à época com 58 anos (nascido em 14/08/1951), informou que seu avô, Inocêncio Bispo da Silva, já falecido, foi antigo trabalhador na extensão da rede de telégrafos, no início do século $X X$, quando se fixou na margem esquerda do rio Correntes. Ele permaneceu no local como responsável pelos cuidados de manutenção da rede no trecho até o rio Piquiri, no atual estado de Mato Grosso. Posteriormente, Manuel Bispo da Silva, filho de Inocêncio e pai de Joel, permaneceu e morou no mesmo lugar, onde até hoje membros da comunidade reivindicam terras de ocupação tradicional. Joel explicou que seu avô paterno, Inocêncio Bispo, chegou a ter a posse da fazenda Lambari, que teria cerca de 12 mil hectares. O imóvel ficaria na margem direita do rio Correntes, alguns quilômetros distantes do porto homônimo. Com sua morte, cada filho recebeu uma parte da propriedade, mas todos perderam tudo, pressionados pelas ofertas de compra feita por novos ocupantes da região. Após este fato, o pai de Joel, de nome Manuel Bispo, teria se casado com Josefa, que já morava nas proximidades do Porto Correntes. Assim, Manuel Bispo teria passado a viver nas terras de posse da família de sua mulher, que lá vivia em comunidade, sendo ela de ascendência indígena e africana. Segundo Joel, seu pai, Manuel Bispo dos Santos, faleceu em 1982, afogado no rio Correntes, época em que o porto havia se transformado em 'pesqueiro' e seu genitor vivia do trabalho como piloto de barco para turistas.

A história da presença na região de Josefa Bispo dos Santos, mãe de Joel, é muito mais antiga. Ele afirmou que sua genitora nasceu no córrego das Flores, na área reivindicada pelo interlocutor como terra da comunidade, mas que fica fora da propriedade que seu pai conseguiu regularizar. A mãe de Josefa, de nome Eugênia Natalina dos Santos (avó materna de Joel), também teria nascido na localidade do Porto Correntes, o que estabelece uma profundidade temporal de mais de um século para a presença da família na área. Este fato remete a um período anterior à virada do século XIX para o XX, pois a mãe de Joel faleceu com mais de 80 anos e a mãe dela também teria nascido na região.

Como indicado anteriormente, a presença do lado paterno da família de Joel é menos antiga na região. Inocêncio Bispo da Silva, o avô paterno de Joel, teria nascido em Cuiabá, capital de Mato Grosso, onde seria pescador. Já adulto, teria trabalhado como empregado da comissão de extensão do telégrafo e, posteriormente, estabeleceu-se nas proximidades do Porto Correntes, quando tomou posse da fazenda Lambari. Para este local, também teria trazido sua família.

A relação entre a família de Inocêncio Bispo da Silva, o avô paterno de Joel que seria originário de Cuiabá, e a família de sua avó materna, nativa da região do Porto Correntes, teria se dado por ocasião de festas. Isto porque o avô materno de Joel, do qual não se lembrara o nome, e sua esposa, Eugênia Natalino dos Santos, sua avó materna, eram festeiros de São Sebastião ${ }^{3}$. Naquele período, Inocêncio Bispo e sua família teriam começado a participar dos eventos. Nos festejos, Manuel Bispo (pai de Joel), filho de Inocêncio, conheceu Josefa, filha do casal de festeiros, com quem veio a se casar.

A partir do casamento com Josefa, Manuel Bispo passou a viver com a família da esposa, que estava radicada desde longa data no Porto Correntes. Posteriormente, Inocêncio Bispo se envolveu em dívidas e perdeu o que restava da fazenda Lambari e, por este motivo, passou a morar com seu filho (Manuel) na localidade das terras da família de sua esposa. Fatos como estes evidenciam que a referência de territorialidade ou de transmissão de

3 O termo 'festeiro' se refere ao patrocinador da festa de São Sebastião, que faz parte da tradição do catolicismo popular. A festa de origem portuguesa foi incorporada ao calendário de festividades religiosas de comunidades tradicionais, indígenas e quilombolas, em diversas partes do Brasil. A inclusão não exclui processos de ressiginificação, nos quais crenças e valores próprios da comunidade local são comunicados a partir dos signos religiosos da tradição católica ibérica. 
direitos territoriais entre as famílias de pessoas negras, que viviam no Porto Correntes, vinculam-se a laços de parentesco baseado na matrilinearidade e matrilocalidade, cujas extensão e profundidade, enquanto princípios orientadores da composição de módulos organizacionais, seriam aprofundadas em novas pesquisas.

A referência do procedimento sociológico de transmissão de direitos territoriais por um cálculo de parentesco unilateral, no caso matrilinear, é bastante conhecida na literatura etnológica para sistemas de parentescos praticados na África ${ }^{4}$. Atestar este procedimento na comunidade Família Bispo é um forte indicador de sua ascendência africana. Trata-se da identificação de uma estrutura de longa duração, na qual um princípio de ordenamento sociológico permaneceu por muito tempo a operar a vida social, mesmo em meio a evidentes transformações históricas. Ao que tudo indica, apenas quando não foi mais possível orientar a conduta coletiva por este princípio é que a comunidade teria entrado numa espécie de colapso, ligado à sua desagregação e fragmentação, intensificado pela impossibilidade de transmissão da posse da terra entre gerações. Entretanto, recentemente novas lideranças femininas se destacam como articuladoras das famílias, o que significa que este princípio de ordenamento poderá ser reavivado.

A lógica matrilinear de transmissão de direitos e de pertencimento territorial, identificada na trajetória histórica do grupo, chocou-se frontalmente com uma lógica distinta e característica de muitas comunidades agrárias no Brasil ${ }^{5}$. Trata-se da lógica de transmissão de direitos territoriais com forte inflexão patrilinear, com seus devidos desdobramentos, que se estabeleceu no Porto Correntes a partir da expansão das frentes de ocupação (neo)colonial.

No caso de Sonora, alguns membros homens da comunidade parecem ter procurado adotar a lógica de transmissão de direitos territoriais pelo parentesco via paterna. Consequentemente, confrontaram-se com a lógica matrilinear que articulou por muito tempo o pertencimento territorial nas antigas famílias ancestrais, de que descendem as atuais famílias que compõem o grupo. Aparentemente, a situação apontada pode parecer uma discussão eminentemente teórica, mas consideramos que o assunto pode contribuir para o entendimento de procedimentos fundamentais da constituição histórica grupal.

É provável que muitos dos problemas que redundaram na desterritorialização da Família Bispo tiveram relação com o confronto entre estas duas lógicas de transmissão de direitos territoriais: uma focada no princípio da matrilinearidade; outra no da patrilinearidade. A interpretação para o processo histórico apontado prioriza as referências institucionais da própria figuração social ali instituída. Entretanto, não é possível omitir o fator desagregador que se irradia a partir das frentes de expansão econômica da sociedade nacional. Elas passaram a disputar a região ao exercerem forte pressão de mudança social. Também impuseram a desterritorialização das famílias de pessoas negras que viviam no Porto Correntes, as quais estavam estabelecidas em terras ocupadas, mas não regularizadas como propriedade privada. $\bigcirc$ argumento apresentado remete, pois, ao fato de que a interferência externa se articula e age a partir de características presentes nas instituições que compunham a configuração social das famílias; explorara eventuais contradições e ambiguidades constitutivas das próprias instituições.

Tudo indica que era difícil, senão impossível, os particulares que buscavam regularizar terras compreenderem a lógica da comunidade focada nos direitos de solo, transmitidos via laços de parentesco matrilineares. Esta forma de transmissão também se distanciava da lógica capitalista de apropriação privada das terras e de seu uso especulativo. Somente foi possível acontecer - e de fato ocorreu - quando o controle do

\footnotetext{
4 Ver, por exemplo, Radcliffe-Brown (1982).

5 Ver, por exemplo, Seyferth (2001), Soares (1981) e Woortmann (1990).
}

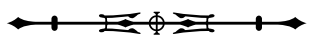


espaço passou às mãos de indivíduos masculinos do grupo, especialmente os que vieram de fora. Esses homens se orientavam pela lógica capitalista ou, pelo menos, tinham maior proximidade com a mesma. Com tal mudança, a terra segue a comportar um valor de uso, mas também passa a ter um valor de troca, traduzível em valor monetário. Foi a agregação da percepção do segundo valor que permitiu que os membros masculinos (ou mesmo as mulheres controladas por homens) gradativamente transferissem a terra para particulares.

Os dados registrados sobre a história da comunidade Família Bispo sugerem, portanto, que enquanto as mulheres exerceram maior poder sobre o território e, consequentemente, o controle político de alguns homens que reivindicavam a autoridade em relação à terra, o espaço permaneceu como de posse coletiva do grupo de famílias. Uma mudança rumo à constituição de uma assimetria de gênero, de modo a favorecer os homens, está historicamente associada ao processo de territorialização, desterritorialização e reterritorialização do lado paterno da família de Joel. Esta situação pode ser verificada a partir do momento em que seu avô consegue a posse de uma extensa porção de terrenos, a exemplo do que fizeram outros particulares não negros. Aparentemente, a área teria sido regularizada como propriedade particular para depois ser vendida a terceiros. No entanto, tudo indica que esta lógica é assimilada apenas parcialmente, uma vez que aquela família de pessoas negras não consegue se firmar como proprietária de terras. Culmina por vender e perder tudo, e depois se viu constrangida a buscar refúgio em território comunitário, controlado por mulheres. Posteriormente, os homens repetem o mesmo procedimento no novo território onde se fixaram, o que acontece tão logo veem enfraquecida a liderança das mulheres, devido às pressões crescentes em torno da disputa pela área. No cenário do Porto Correntes, esta situação se deu após a morte de Josefa Bispo, a última líder familiar feminina que ainda conseguiu manter a apropriação do território sob lógica feminina, onde também exercia a prerrogativa de articuladora do grupo familiar ${ }^{6}$.

Foi possível ainda constatar que, na Família Bispo, o local de nascimento das mulheres tornou-se uma referência importante nos mecanismos de construção e manutenção da identidade com o território. As mulheres tenderam a viver mais na comunidade, enquanto os homens, principalmente quando jovens, aventuravam-se em espaços fora do grupo, até mesmo em outros estados da federação. Desta forma, os membros masculinos tenderam a se apresentar como mais abertos à exterioridade, quer dizer, atuaram de modo a incorporar a lógica territorial dos membros de fora da comunidade, com os quais mantinham intensa e frequente interação. $\mathrm{Na}$ maioria das vezes, os contatos ocorriam quando trabalhavam como mão de obra na implantação de fazendas. Mesmo que de forma inconsciente, os homens acabaram por facilitar a dissolução da lógica territorial própria à comunidade. Este processo se intensificou nas últimas décadas do século $X X$.

A história de vida do próprio Joel reflete bem esta mobilidade espacial. Até os 17 anos, ele viveu boa parte do tempo com o avô paterno, quando este ainda dispunha de um pedaço de terra fora da área de herança materna. Também frequentava por temporadas a casa de seus padrinhos, que não faziam parte da Família Bispo, pois eram fazendeiros, embora também fossem negros, vindos de Minas Gerais? Afirma ter vivido temporadas em diversos estados da federação, como São Paulo, Rondônia e Acre, sempre a

6 Os irmãos Joel e Teka foram enfáticos ao associar o falecimento da mãe à fragmentação da comunidade. Para Joel, a compra de uma casa em Sonora e a mudança dos membros mais jovens para aquela cidade, a pretexto de estudarem porque lá teriam acesso facilitado à escola, é apontado como o início do processo de esfacelamento da unidade da família extensa.

7 Joel afirma que seus padrinhos eram 'negros mesmo', enquanto sua família tinha mistura, principalmente de indígena, por parte de sua avó materna. A mãe de sua mãe era filha de índia Bororo, pertencente a uma comunidade que vivia nas proximidades do Porto Correntes, com quem seu bisavô, que era negro, contraiu matrimônio. 
serviço de fazendeiros: peão de boiadeiro, segurança de fazenda, sitiante, dono de tropa, barqueiro, tratorista etc. A cada uma dessas profissões correspondem momentos para a aprendizagem de novos conhecimentos, além de oportunidades para viver novas aventuras amorosas ou de socialização com outros segmentos da sociedade nacional. Em uma dessas aventuras, no estado de Rondônia, município de Pimenta Bueno, o interlocutor relata que trabalhou como segurança para um fazendeiro de nome Guerreiro:

[...] eu cuidava da beirada do rio, assim, da linha 15 até a linha 21; ele comprou uma gleba, uns 30 mil alqueires, então eu fazia o serviço de barco na beira do rio. Lá, os caras eram tudo brabo... arma braba, tudo brabo; eu entrei na área pra trabalhar, eu e o Assis, gerente de Prudente... O Assis ficou três meses e depois vazou. Cara, lá encosta no porto assim, ó o tamanho da arma... revólver pra todo lado..., mas eu ganhei muito dinheiro, puxava mercadoria para a turma das glebas... o patrão sabia... fazia amizade com o povo da gleba pra puxar carga, fazia festa, fazia churrasco, era tudo amigo da gente..., mas depois ele perdeu tudo aquela beira de rio [ênfase adicionada] (Joel Bispo, comunicação pessoal, ago. 2008).

Outro exemplo desta perambulação é quando relata a morte de seu pai: "[...] quando o pai morreu foram achar eu lá na fazenda [na região de Três Lagoas, Mato Grosso do Sul]; aprendi a mexer com trator, já tava virado, outra vida...". Combina-se aí o desterro dos homens em busca de soluções para os problemas provocados pela perda gradativa das terras, à época controladas pelo grupo de mulheres, com a procura de novas experiências, nitidamente centradas em formas de sociabilidade masculina. Assim, os homens da família são forçados a buscar novas oportunidades, mas também são movidos pelo desejo de aventura, presente nas narrativas de Joel.

Joel Bispo dos Santos afirmou que seu avô teria sido um dos responsáveis por algumas equipes que trabalharam na extensão da rede de telégrafos. Como naquele tempo as terras do Porto Correntes eram todas consideradas devolutas, resultou que alguns trabalhadores da rede de telégrafo acabaram por se fixar no local. Relatou, ainda, que, com a desativação do telégrafo, os postes de aroeira que sustentavam a rede foram retirados por particulares e levados para suas respectivas propriedades. Segundo o próprio Joel, seu pai relatava que a primeira pessoa a se apresentar como proprietária na região foi um senhor denominado Evaristo, que se autodenominava gerente de Fernando Corrêa da Costa, então governador de Mato Grosso $^{8}$. Evaristo teria tomado posse de uma área de mais de 40 mil hectares de terras devolutas; em seguida, passou a revendê-las em parcelas menores para outros particulares. Joel mencionou ainda que "naquele tempo isto aqui tudo era um largão" (comunicação pessoal, ago. 2008). Recorreu a uma expressão regional para se referir ao fato de que no passado havia pouca presença de outros moradores na área, além de praticamente inexistirem espaços transformados em propriedade privada da terra naquela parte do antigo Mato Grosso. Explicou que os primeiros ocupantes de várias áreas, que denomina como 'o pessoal antigo', perderam todas as terras para os que vieram de outras regiões, os quais tinham a mentalidade de cercar e titular os espaços. Em suas palavras:

[...] naquele tempo não tinha dono, cada um ocupava uma região, depois o pessoal foi chegando e medindo por conta e fazendo... e foram tomando conta... 으 pessoal daqui foi perdendo, foi perdendo, foi perdendo... chegava os grandes, cercava tudo e entrava... Esse aí que é o problema... Naquela época não, moda nós aqui nós criava o gado tudo misturado, não tinha cerca, não... Só tinha a marca...., cerca era a terra, terra mesmo ninguém ocupava [ênfases adicionadas] (Joel Bispo, comunicação pessoal, ago. 2008).

mesmo interlocutor, ao se referir à terra reivindicada por famílias da comunidade Bispo, relatou que:

\footnotetext{
8 Fernando Corrêa da Costa, nascido em Cuiabá no ano de 1903, e falecido em Campo Grande, em 1987, foi prefeito de Campo Grande (1948-1951), governador do estado por dois mandatos (1951-1956 e 1961-1966) e senador da República por duas legislaturas (1959-1961 e 1967-1975). Durante seus governos, muitos territórios indígenas foram titulados a favor de terceiros no antigo Mato Grosso (Eremites de Oliveira \& Pereira, 2009).
}

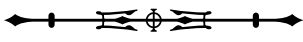


[...] essa área a gente usava.... Na época ninguém tinha título de terra aqui, não; era um mundo aberto, cada um cercava um pedaço de terra ${ }^{9}$ e usava, do largão ${ }^{10}$ pra lá inté a lagoa da Serra era os índios que fica pra lá, pro lado da fazenda São Pedro, onde era babaçuzal, era os índios que usava; não era terra de fazenda, eu lembro... Era de índio Bororo, daí chegou fazendeiro... Matou o Zé Gralha... Não quis desocupar, mataram ele... Foi o filho do telegrafista que matou ele, por causa de terra; no fim a terra não era de ninguém, era de todo mundo.. Dividiu e tirou todo mundo. Tem um deles que mora aí em Rondonópolis, o Dorvalino [outro Bororo], ele é até parente da gente pelo lado da mãe; viviam nesse mundo aí cortando mel; sabe que eles é vagabundo mesmo, mas era eles que morava aí, era terra deles... Fazendeiro forte tirou eles destas terras... Essa parte que nós morava... aqui foi o governador Fernando Correia da Costa... O Evaristo era gerente, ele pôs o Varistão; ele acertou com ele, daí ele pegou e vendeu tudo... Ele era governador, ele mandava em tudo. A fazenda dele [do governador] era a fazenda São Pedro, de 27 mil hectares [ênfases adicionadas] (Joel Bispo, comunicação pessoal, ago. 2008).

Até a década de 1970, predominava um clima de cooperação entre as pessoas que compunham a comunidade; existiam festas e cerimônias religiosas que atualizam laços de pertencimento e cooperação. Joel afirma que havia, inclusive, mutirões: "[...] era só nós aqui mesmo; a gente se ajudava.... Quando alguém tinha roça suja, o pessoal se reunia e fazia a surpresa, aparecia na roça e começava a trabalhar; daí o dono da roça tinha de correr atrás do rango" (comunicação pessoal, ago. 2008). A partir desse momento, começam a diminuir os mutirões, o que coincide com a consolidação do domínio exercido pelos 'fazendeiros fortes'. Decorre daí a oposição de duas categorias êmicas com as quais a comunidade opera: 'fazendeiros fortes', categoria referente aos novos ocupantes da região, aqueles que titularam a área em nome de particulares e excluíram todas as formas anteriores de ocupação e uso da terra; e 'fazendeiros antigos', com os quais os membros da comunidade Bispo se relacionavam mais intensamente e que faziam parte de redes de alianças ampliadas, mantidas através de cooperação econômica, relações de compadrio e rituais religiosos.

Na sua compreensão, a morte de seu pai, Manuel Bispo, consolida o processo de esfacelamento das famílias da comunidade porque vários de seus filhos, entre eles José, Elsa, Filomena e Genivaldo, começaram a dividir a porção da terra que acreditavam corresponder à sua herança, procurando vendê-la a terceiros. Lúcia dos Santos Bispo, irmã de Joel, alega que seus irmãos venderam as terras por necessidade. $O$ processo de transferência das terras passa a ser facilitado devido à sua valorização, já que a região passa a ser disputada para a instalação de pesqueiros. Com a morte de Manuel, sua esposa Josefa passou a controlar os bens da família, mas, segundo Joel, "os filhos começaram a dobrar a mãe" (comunicação pessoal, ago. 2008). Joel também afirmou que, quando sua mãe ficou viúva, ela resolveu alugar uma casa na cidade sob pretexto de facilitar o estudo dos filhos. Ele considera esta decisão um grande erro, pois apenas sua irmã Lúcia aproveitou a vida na cidade, já que estudou e conseguiu emprego como professora. No mais, acredita que a ida dos irmãos para o perímetro urbano de Sonora dispersou mais ainda o grupo familiar, desarticulou a produção do sítio e enfraqueceu o vínculo com a propriedade. A partir de então, explica que os filhos começaram apenas a tirar lucro do sítio e acabaram por vender todo o gado. Assim, em sua visão, a mudança para cidade foi um passo fundamental para desarticular a comunidade, já enfraquecida pelo processo de mudança no estilo de ocupação das terras.

Joel também relatou que Aparecido José da Silva é um dos novos proprietários que comprou terras de seus irmãos. À época das pesquisas, ele estaria muito bravo

\footnotetext{
9 O que era cercado na verdade eram as roças, já que o gado era criado solto, inclusive tinha gado bagual, ou seja, criado sem dono, alongado, pois não tinha marca, sendo que qualquer pessoa podia marcar o boi bagual, que, então, passava a ser de sua propriedade. Também se costumava fazer um pequeno piquete para vacas leiteiras ou para animais que necessitavam de cuidados especiais.

10 Largão é também a expressão que utiliza para designar a região não ocupada por posseiros ou proprietários, como a região onde vivia um grupo de famílias indígenas, do qual descenderia sua avó, mas que depois foi dali removido ou abandonou o local.
}

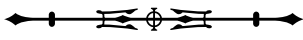


com a reivindicação territorial das famílias da comunidade Família Bispo; também teria feito ameaças constantes a pessoas do coletivo quilombola. Um complicador adicional é que Aparecido teria se casado com uma neta de 'Tia' Chica (Francisca dos Santos), irmã de Josefa; as duas irmãs tornaram-se líderes de partes da comunidade e se apresentavam como rivais. Isto fez com que aflorasse o histórico de conflitos descrito no relatório do analista em antropologia do MPF, mencionado anteriormente. Ocorre que, em tempos pretéritos, houve a oposição do grupo familiar de 'Tia' Chica, situado na margem direita do rio Correntes, em Mato Grosso, e o de sua irmã Josefa, localizado no lado esquerdo do rio, em Mato Grosso do Sul, o que envolveu, entre outras coisas, acusações de agressões rituais.

Ele afirmou, ainda, ser afilhado de Orlando Vilela e Cecília Vilela, dois irmãos que vieram de Minas Gerais e se tornaram donos da fazenda São Benedito; também eram negros e se entendiam muito bem com a comunidade da Família Bispo. O casal se encaixa na tipologia de 'fazendeiro antigo', descrita anteriormente. Nota-se a existência de uma relação assimétrica entre pessoas negras na região, pois, como afirma Joel, eles "eram os pretos mais fortes, tinham 10 mil hectares" (comunicação pessoal, ago. 2008). A assimetria também se expressa na relação padrinho-afilhado porque na região é comum a família do padrinho ter um status econômico superior à família do afilhado. Importa registrar que a fazenda São Benedito estava situada a cerca de $6 \mathrm{~km}$ do local onde viviam e, ademais, o casal de padrinhos também deixou a fazenda e passou a viver em Rondonópolis, Mato Grosso. À época dos trabalhos de campo, apenas uma sobrinha do casal vivia na cidade de Sonora e estava casada com um primo de Joel, de nome Zeti, provavelmente Donizete. Também informa que foi batizado na fogueira, na fazenda São Benedito, com tição; depois, o batizado foi realizado na igreja católica.

Joel Bispo explica que, naquele tempo, todo mundo criava gado junto; só diferenciava pela marca. Os Bororo também tinham gado e ele se lembra de um que era chamado de Raimundo Bugre. Os índios também tiravam babaçu e vendiam a castanha. Nesse período, costumavam visitar os membros da comunidade da Família Bispo; alguns deles eram Chiquinho e seu irmão, Zé Gralha, que teria sido morto a mando de fazendeiros interessados em tomar posse da terra dos índios. Afirma ter notícia de que Chiquinho ainda vive na cidade de Pedro Gomes, em Mato Grosso do Sul, e que "cada pé de serra onde tinha água tinha os bugres"11 (comunicação pessoal, ago. 2008).

O contato com os índios ocorria devido à proximidade geográfica e aos laços de sangue, já que o referido interlocutor afirma que sua bisavó era Bororo: "foi pega a laço" e seria mãe de Eugênia, sua avó12 (comunicação pessoal, ago. 2008). Assim, o lado materno da família de Joel teria uma ascendência mista, dividida entre membros Bororo e negros; estes últimos teriam se estabelecido na região ainda no século XIX, provavelmente pessoas escravizadas fugidas de fazendas ou recém-libertas. Esta proximidade com os índios estreitou e aprofundou o forte vínculo com o território e, por conseguinte, permitiu incorporar uma série de conhecimentos relativos a formas de manejo e uso dos recursos ambientais presentes na região. Significa dizer

\footnotetext{
11 Esta afirmativa de Joel Bispo remete à existência de um sistema de assentamentos dos Bororo no norte do atual estado de Mato Grosso do Sul. Viviam às margens de córregos que nascem nas serras e correm para os rios da região, como o Correntes e o próprio rio Pedro Gomes. A existência desses assentamentos sugere que, entre fins do século XIX e as primeiras décadas do XX, os Bororo e também os Kayapó teriam sido expulsos das margens dos grandes rios da região, cujas áreas foram transformadas em propriedade privada (fazendas de gado).

12 Segundo E. Lima \& Eremites de Oliveira (2017, p. 15): "Expressões do tipo 'minha avó foi pega a laço' ou 'minha bisavó foi pega a dente de cachorro', tão comuns no país e por vezes pronunciadas em tom jocoso, revelam muito da violência sofrida por mulheres indígenas desde o início da invasão europeia do continente. Seus corpos amiúde são os primeiros a registrarem as marcas da violência durante o encontro colonial".
}

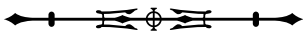


que a comunidade passou a se configurar como coletivo sociocultural afro-indígena ${ }^{13}$.

Das pessoas da Família Bispo com as quais tivemos oportunidade de conversar, Joel foi o que mais demonstrou conhecimento sobre a história da presença de sua família na região. Como dito antes, ele e seus irmãos nasceram na antiga casa de seus pais, Manuel e Josefa, já falecidos, situada no Porto Correntes, margem esquerda do rio homônimo. $\mathrm{Na}$ época da pesquisa de campo, a residência ainda existia e pertencia à sua irmã, Lúcia Bispo. Ela morava na casa, embora se deslocasse todos os dias até a cidade de Sonora, onde trabalha como professora da rede municipal. Ficamos hospedados na casa de Lúcia e durante o dia visitávamos Joel ou recebíamos a visita deles e de vizinhos que vinham conversar conosco. No início da noite, quando Lúcia retornava para sua casa, era o momento que havia para conversar mais tranquilamente com ela, sempre hospitaleira e atenciosa.

No momento de realização da primeira etapa da pesquisa, foi possível notar que a referência de territorialidade da Família Bispo esteve focada na casa que Lúcia herdara de sua mãe, o que pode ser mais um indicativo da matrilinearidade na transmissão do território. Não obstante, apareceram evidências de ocupação de um território bem mais amplo, sobre o qual os membros da comunidade gradativamente perderam o controle, o que se deu a partir da chegada das frentes de expansão agropecuária. Tudo indica que a primeira residência dos membros mais velhos da família ficava no córrego das Flores que, segundo Joel, distava cerca de 2,5 km da casa ocupada por Lúcia.

Outro indicativo importante foi a ascendência matrilinear da família, embora seus membros tenham adotado oficialmente o sobrenome Bispo. Uma hipótese seria de que Josefa e Manuel tivessem o mesmo sobrenome, ou mesmo que fossem parentes distantes, como primos ou parentes em segundo grau. De qualquer forma, pelo lado materno, todos têm como referência de nascimento o córrego das Flores.

Do lado da família radicada na margem direita do rio Correntes, em Mato Grosso, grande parte das terras antes ocupadas por 'Tia' Chica foi incorporada pela fazenda Salgueiro. A importância do enfoque no parentesco matrilinear se evidencia na cisão da comunidade, quando as duas irmãs, Josefa e Francisca, se desentenderam. Cada uma se manteve em uma das margens do rio, acompanhadas pelas famílias que reconheciam a liderança feminina. A partir daí, a comunicação entre as duas famílias foi interrompida e os dois grupos seguiram como comunidades independentes. Não foi possível visitar a família de dona Chica (Francisca dos Santos), mas Joel informou que um dos filhos dela, de nome Isaías, vive na cidade de Sonora. Joel indicou, ainda, a existência de outro irmão de sua mãe, de nome Zacarias, que vive atualmente em Coxim, Mato Grosso do Sul, que seria grande conhecedor da história da região.

A família é designada de Bispo por imposição da lógica de parentesco do sistema nacional, que tem uma inflexão patrilinear na transmissão do sobrenome, mas poderia ser denominada de Santos. Outra questão importante é que a ocupação tradicional dos membros da família se estendia pelos dois lados do rio até ocorrer a divisão do grupo, sendo que os do Mato Grosso, entre outras coisas, não se reconhecem pela nomenclatura Bispo.

\section{ANÁLISE DOS PROCEDIMENTOS E IMPASSES NO PROCESSO DE REGULARIZAÇÃO FUNDIÁRIA}

Marcos Homero F. Lima, citado anteriormente, costuma dizer que os processos de regularização fundiária de terras

\footnotetext{
13 Embora no conhecido mapa etno-histórico de Nimuendajú (2017) também conste registrada a presença dos Kayapó na região e adjacências, os interlocutores quilombolas apenas fizeram menção à presença dos Bororo naquela parte da bacia do rio Correntes e proximidades, ao menos desde fins do século XIX e primeiras décadas do XX. Este assunto, porém, precisa ser estudado com maior profundidade, pois a ideia de que os Bororo e Kayapó estariam 'extintos' no estado não mais se sustenta. Serve apenas para corroborar teses colonialistas acerca da existência de vazios demográficos em áreas ocupadas pelas frentes de expansão da sociedade nacional.
} 
indígenas acabam por se desmembrar em três: o político, o administrativo e o jurídico (M. Lima \& Guimarães, 2009). Em comunicação pessoal, identificou a possibilidade da consideração de um quarto procedimento, que seria o cognitivo, a partir do qual a comunidade elabora a compreensão dos outros três processos e a compreensão das relações de interferência recíproca entre eles. Consideramos sua ideia bastante inspiradora para a análise dos impasses vividos no processo de regularização fundiária do território da Família Bispo. Por isso, tomamos emprestado o esquema proposto para analisar o caso em destaque a partir do processo político, já que o processo administrativo está interrompido e, como ele não foi concluído, não há processo jurídico de contestação em relação a seu conteúdo.

O processo político, sobre o qual mais nos detemos aqui, refere-se ao modo como os membros da Família Bispo se organizaram ou se reorganizaram para compor a comunidade política atual. $O$ coletivo passou a demandar junto ao INCRA a regularização de um território considerado como de ocupação tradicional. Vale lembrar que a maior parte das comunidades quilombolas que vivem em Mato Grosso do Sul passou ou passa por processos parciais ou totais de expropriação territorial. Em alguns casos, membros desses coletivos lograram regularizar áreas pelos meios legais de compra e venda de terras. Os terrenos adquiridos, mesmo aqueles que não correspondem à totalidade da área ocupada, transformaram-se em referência para a reprodução de memórias e práticas relativas às formas de territorialidade.

No caso da Família Bispo, a maior parte das famílias que compuseram a comunidade perdeu gradativamente a base territorial, aquela onde se reproduzia física e culturalmente. $\bigcirc$ território de uso exclusivo ficou restrito ao lote de terras titulado em nome de Manuel Bispo da Silva e Josefa dos Santos. As áreas do entorno foram ocupadas por terceiros, que não mais permitiam o uso delas por pessoas do grupo. Dessa forma, a terra insuficiente impôs o deslocamento de muitos parentes para outros lugares, principalmente para o núcleo urbano de Sonora.
Outra parte da família logrou permanecer numa área situada à margem direita do rio Correntes, em Mato Grosso. A dispersão causou sérios prejuízos ao grupo, promovendo o distanciamento entre as pessoas e enfraquecendo os laços de convivialidade. Estes vínculos são expressos em formas de vizinhanças, relações de compadrio, cooperação econômica, participação conjunta em eventos festivos e religiosos e compartilhamento de uma liderança comum, responsável pela orientação dos membros na conduta política. $\bigcirc$ distanciamento entre as pessoas criou sérias dificuldades para o reatamento dos laços comunitários e, ademais, para a atualização do processo que permitiria que as famílias se representassem como comunidade política. Este último fato foi agravado por pressões que recebiam de proprietários particulares para que renunciassem à demanda territorial.

Muitas pessoas passaram anos ou décadas fora do local e depois retornaram à região, como foi o caso de Joel Bispo, sobre o qual já foi discorrido. A partir do momento em que algumas delas tomaram conhecimento da possibilidade de reaverem o território de ocupação tradicional, através da ação de regularização fundiária proposta pelo INCRA, passaram a se defrontar com o desafio de recompor suas relações de convivialidade. Entretanto, até o momento dos trabalhos de campo, em 2008, e ao tempo da escrita deste estudo, não venceram o desafio de novamente se (re)pensarem e atuarem enquanto comunidade política com demanda territorial precisa. Dito de outra maneira, o grupo não superou a difícil etapa de sua recomposição. As pessoas se percebem como parentes consanguíneos, da mesma forma que reconhecem a história comum da família no posto de telégrafo do rio Correntes. Todavia, existe a cisão entre os que se identificam como quilombolas e reivindicam a titulação coletiva da terra, representados por Joel Bispo e Lenilson Bispo, e os que preferem desistir da demanda, posição adotada na época pela maioria da família. $\bigcirc$ assunto permanece como tema de recorrente discussão interna, ainda à espera de um melhor desfecho. 
Do ponto de vista antropológico, uma comunidade quilombola é uma comunidade étnica e, portanto, comunidade política na acepção weberiana (Weber, 1969, 1973). Esta constatação não é, contudo, uma realidade autoevidente. Os grupos humanos que assim se apresentam enfrentam, portanto, o desafio renovado de superar as dificuldades de relacionamentos entre seus componentes e mesmo as ameaças de cisões e fragmentação interna. Resulta daí que a realidade de uma comunidade é sempre recriada. Esta recriação não repete rigorosamente os processos sociais já praticados no passado, embora se constituam em importantes referências para sua continuidade. Reconhecemos, assim, que toda sociedade é histórica, inserida em uma dinâmica de eterna transformação, mas paradoxalmente dependente de estruturas de replicação que, de alguma forma, assegurem a reprodução social.

A necessidade de ativar os laços de convivialidade enfrentou o desafio de anos de afastamento entre as pessoas da Família Bispo. A instigação tornou-se ainda maior devido aos diversos conflitos com membros externos da comunidade. Estas contendas ocorreram em todo o período de expropriação do território, com uma explícita omissão do Estado nacional, que nada fez para assegurar seus direitos. A reclusão territorial das famílias ao lote regularizado em nome de Manuel Bispo obrigou-as a abandonar as áreas regularizadas em nome de terceiros, os quais se estabeleceram na região como proprietários de terras adquiridas junto ao governo de Mato Grosso. O confinamento territorial dificultou a convivência interna na comunidade e intensificou os conflitos entre seus componentes. Durante décadas, foram intensas as disputas territoriais no entorno da área ocupada pelos membros da Família Bispo; por vezes, alguns deles teriam se envolvido nos conflitos, o que contribui para dificultar a convivência interna. $\bigcirc$ argumento aqui apresentado é que a violência que predominava em Sonora repercutiu como um imperativo do sistema sociocultural ali instituído, do qual a comunidade fazia parte. Muitos de seus membros parecem ter assimilado tais práticas e, como resultado, violências também teriam ocorrido no interior do grupo, já fragilizado pelo processo de perda territorial. Há relatos sobre a dificuldade em controlar o recurso à violência entre os parentes, sobretudo após a expropriação territorial, algo que antes era assegurado por formas próprias de promoção da pacificação, correlacionadas com conhecimentos e práticas de produção da sociabilidade.

A partir das contribuições teóricas da antropologia social e do inventário em etnografias produzidas em diversas regiões do mundo, torna-se possível afirmar que em qualquer formação social humana a vida social é composta por vetores de aproximação, expressos em diversas formas de convivialidade e solidariedade. No entanto, esta situação também comporta elementos de repulsa social entre pessoas ou facções, manifestados em conflitos de interesses, os quais muitas vezes tendem a dispersar ou fracionar os grupos. Esta realidade também gera processos de produção social e de assentamentos especíicos a cada coletivo humano. As formas de convivialidade procuram gerir e administrar os eventuais conflitos que fazem parte da dinâmica social. Para que qualquer grupo social possa se apresentar como coletividade, torna-se necessário que mantenha os conflitos políticos sob controle. $\bigcirc$ modo como se produz este controle varia entre as comunidades, mas normalmente é alcançado através da promoção periódica de aconselhamentos, rituais, festas, eventos políticos e demais condutas que reforçam os laços de cooperação e solidariedade. São práticas fundamentais para afastar o risco permanente de conflitos incontroláveis.

O controle ao qual nos referimos era mantido na comunidade da Família Bispo por meio de uma série de práticas religiosas, como as festas de santos, e mesmo pela cooperação no trabalho em mutirões para a confecção de casas e roças. Aos poucos, a comunidade deixou de ter estas referências devido a fatores como desterritorialização, dispersão dos membros, surgimento de contendas não resolvidas entre parentes e morte dos líderes mais velhos, que gozavam de prestígio e autoridade para resolver os conflitos. 
Relativo ao assunto, Strathern (1988) apresenta o conceito de 'socialidade' como tentativa de incorporar, sob um mesmo rótulo ou neologismo, as formas de expressões das relações sociais que comportam vetores de aproximação e repulsa social. A tentativa é criar um instrumento teórico-metodológico que permita reconhecer e dar expressão analítica a situações da interação social. Um dos propósitos é fugir da imagem durkheimiana que prioriza a coesão como fundamento da vida social, embora Marx \& Engels (1986) e Weber (1969), entre outros autores, já tenham apontado questões semelhantes sob outras palavras. Assim, na perspectiva que procuramos adotar neste trabalho, o conceito de socialidade é diferente do conceito de sociabilidade. Sociabilidade se restringe a apresentar os mecanismos de aproximação social, como normalmente são descritos, a exemplo das atividades festivas ou de confraternização. Já o conceito de socialidade, por sua vez, parte do pressuposto de que a ação social pode comportar elementos de rivalidade, competição e atrito, presentes mesmo em eventos festivos avaliados como puros atos de sociabilidade. Uma ação de socialidade pode tender mais para a harmonia ou mais para a ruptura do tecido social, mais isso somente pode ser avaliado a partir da descrição e análise de cada caso. A ruptura pode ser necessária à composição de novo arranjo relacional e está inserida, em vista disso, nos processos de reprodução social. De todo modo, a fratura do tecido social gera materiais para novas formulações. Daí o reconhecimento crescente da importância da categoria 'transformação' no estudo dos processos sociais, cujo assunto não consta aqui desenvolvido à altura por não fazer parte do tema central do artigo.

Considerando a impossibilidade da vida social se compor apenas com atos de sociabilidade, torna-se necessário reconhecer que ela requer a combinação de um coeficiente mínimo destas práticas. Isto precisa ser feito de modo suficiente para manter o sentimento de solidariedade de grupo, bem como à manutenção da percepção de pertencimento a um coletivo particular frente a outros grupos, potencialmente rivais ou concorrentes.
É possível afirmar que a redução das práticas de sociabilidade e o predomínio dos conflitos acabou, no tempo presente, por impedir que a Família Bispo se sentisse suficientemente segura para seguir com a demanda territorial. Dessa maneira, a discussão a respeito do conceito de socialidade, e dos vetores de aproximação e repulsa social que inevitavelmente comporta, pode ser útil à discussão acerca do processo político da comunidade. Outro elemento a ser considerado diz respeito à eficiência dos mecanismos de administração e resolução de conflitos, cuja centralidade estava sob a responsabilidade dos líderes mais velhos do grupo, em especial as mulheres. Os líderes que os sucedem agora parecem não mais dispor do mesmo domínio dos procedimentos, visto que a expropriação territorial e a dispersão das famílias estariam na base das dificuldades de transmissão dos papéis de liderança.

Com efeito, a dificuldade de promover ações de manutenção e fortalecimento do sentimento de pertencimento a uma comunidade específica comprometeu o processo político. Somente a determinação em manter o vínculo comunitário, via associação, como requerido pela legislação brasileira, permitiria que a Família Bispo decidisse pela continuidade do processo de regularização fundiária.

A análise do comprometimento do processo político do grupo não pode deixar de fora a análise do papel do movimento negro e quilombola, que inclui vertentes e orientações políticas diversas. Todavia, costuma se colocar como interlocutor das lideranças de comunidades remanescentes dos quilombos no Estado. As discussões desenvolvidas pelos líderes do movimento parecem não ter sido suficientes para informar os membros da Família Bispo a respeito da complexa situação que teriam de enfrentar. A partir do momento que tomaram a decisão de se apresentarem como quilombolas à sociedade nacional envolvente e ao Estado brasileiro, passaram a reivindicar direitos territoriais. Isto tudo favorece a exposição ao conflito com os proprietários que se estabeleceram no antigo território, pois nega a lógica da subordinação a eles imposta pelas elites locais. 
As visitas dos líderes do movimento negro e quilombola a integrantes da Família Bispo foram esparsas e insuficientes. Em grande medida, isso se deve aos parcos recursos de que dispunham para esta finalidade. Dessa forma, não foi possível dirimir todas as dúvidas sobre as implicações políticas da decisão de se apresentarem como comunidade quilombola. As falas de alguns membros da família, durante a audiência realizada na comunidade, deixaram bastante explícitas a crítica ao apoio insuficiente que receberam do movimento negro e quilombola. Segundo algumas pessoas disseram, isto promoveu a falsa sensação de que tudo seria muito mais fácil do que acabou por se revelar. Naquele lugar, o Estado não se faz presente de forma eficaz e moralizadora o tempo todo. Sua presença é esporádica, como no caso das visitas de servidores do INCRA e do MPF, além de pesquisadores ligados a universidades. Fatos assim despertam a atenção dos proprietários contrários à regularização da terra, inclinados a redobrar a vigilância e aumentar as pressões sobre membros do grupo.

O processo político não foi suficientemente amadurecido, especialmente no que se refere ao enfrentamento com os proprietários que vieram a se opor ao processo de regularização fundiária. O grupo de pessoas da Família Bispo, mobilizado para a reivindicação do reconhecimento enquanto coletivo quilombola e para a regularização fundiária, encontrava-se, à época dos trabalhos de campo, insuficientemente preparado para o embate político. Também estava dilacerado por conflitos internos, com participação direta de agentes políticos interessados na não regularização da terra. Quando a reação dos proprietários se tornou mais veemente, inclusive com ameaças à integridade física das pessoas, a maior parte dos membros não suportou e decidiu desistir da reivindicação para ficar livre das ameaças. A ausência histórica do Estado na ação em favor dos direitos da comunidade era, pois, um fator relevante no convencimento de que agora a situação não seria diferente. $O$ próprio Estado se ausentaria e os membros da comunidade ficariam à mercê das recorrentes violências.

Sem dúvida alguma, o maior fator de enfraquecimento do processo político foi a ausência do Estado, que, segundo a expressão de alguns membros da comunidade, 'chegou muito tarde'. O estabelecimento do Convênio INCRA/ UFGD gerou a expectativa de que o processo administrativo seria ágil, o que não foi confirmado. O início e a interrupção dos trabalhos motivaram a intensificação das pressões sobre a comunidade, que ficou à mercê de ameaças e constrangimentos, muitas vezes sem ter a quem recorrer.

No dia 8 de maio de 2009, foi realizada a 'última' reunião oficial com membros da comunidade em uma audiência local. Estavam presentes a presidente da Associação Quilombola Família Bispo, Lúcia Bispo, e os demais filhos da falecida Josefa Bispo. Uma socióloga do INCRA abriu a reunião e discorreu brevemente sobre os procedimentos que fazem parte do processo de regularização fundiária. A reunião contou com a presença de autoridades do referido órgão público, uma de Brasília e outra de Campo Grande, além do procurador da República Emerson Kalif Siqueira, do MPF, na capital do estado. Pelo movimento negro e quilombola, estavam presentes três dirigentes e uma liderança da comunidade de Picadinha, do município de Dourados, representando a coordenação do movimento quilombola em Mato Grosso do Sul.

Uma representante do INCRA em Campo Grande passou a palavra para o superintendente do órgão no estado. Em seguida, ele pediu que as outras pessoas não integrantes da comunidade se retirassem da reunião. Assim o fez para que o encontro fosse realizado apenas com os membros da Família Bispo, haja vista que não se tratava de audiência pública, a qual poderia ser realizada em outro momento. Algumas pessoas reagiram e não queriam sair; foi necessário que agentes da Polícia Federal presentes na ocasião as retirasse. $\bigcirc$ superintendente explicou que estava lá para dirimir todas as dúvidas em relação ao fato de a família seguir na demanda da realização do processo de regularização fundiária e, ademais, gostaria 
que a comunidade se expressasse com liberdade e sem nenhuma espécie de cerceamento. Contraditoriamente, o constrangimento já estava instaurado e interferiu no posicionamento das pessoas.

A servidora da comissão de regularização fundiária do INCRA fez um breve histórico das lutas e conquistas dos negros no Brasil. Explicou a atribuição do instituto na regularização fundiária, os passos da legislação de tramitação do processo administrativo e os possíveis impasses judiciais. $\bigcirc$ representante da comunidade de Picadinha também relatou a experiência de regularização das terras no município de Dourados.

Lúcia Bispo, presidente da Associação Quilombola, expôs o posicionamento da maior parte dos presentes e apresentou a desistência da comunidade em relação ao processo de regularização fundiária. Afirmou ter se interessado por ser quilombola por causa dos benefícios, sem saber o que isso implicava; achava que a vida iria mudar da água para o vinho, mas isso não aconteceu. Afirmou ter 11 hectares e que desejava vender uma parte para reinvestir na propriedade. Por este motivo, manifestou o desejo de desistir de ser quilombola. A discussão foi intensa, pois os irmãos Joel e Denilson não queriam a renúncia. Entretanto, houve uma votação e a posição dos dois foi vencida. A questão que permanece é se ainda é possível retomar o processo de regularização da terra e como isto poderia ser realizado. Pesquisadores que atuam junto à comunidade Família Bispo, especificamente em programas de compensação por impactos ambientais de empreendimentos instalados na região, informam a permanência do sentimento de pertencimento comunitário e o desejo de novamente recolocar a demanda em pauta. Portanto, o processo não estaria morto e há intensa discussão na comunidade sobre como reavivá-lo.

\section{CONSIDERAÇÕES FINAIS}

O caso da Família Bispo permite pensar sobre os dilemas envolvidos no esforço atual de regularização fundiária dos territórios de comunidades quilombolas em Mato
Grosso do Sul e em outros estados brasileiros. $O$ acesso legal à propriedade da terra, especialmente a partir do período republicano, priorizou o requerimento formal, o recolhimento das taxas e os procedimentos de demarcação física dos terrenos. As áreas regularizadas como propriedade privada deveriam ser devidamente documentadas e preferencialmente cercadas. Comunidades indígenas, quilombolas e outras tradicionais, todas sem recursos financeiros e conhecimento apurado acerca dos procedimentos estabelecidos em lei, ficaram historicamente alijadas do processo de regularização fundiária, mesmo quando estavam de posse das terras tradicionalmente ocupadas. A chegada de terceiros, a maioria já proprietária de áreas em outros estados, interessados em requerer e titular terras consideradas públicas (devolutas), deixou as comunidades expostas a um processo violento de expropriação territorial, que em alguns casos perdura até a atualidade.

Ao longo de mais de um século, a ação do Estado foi francamente contrária aos direitos territoriais das comunidades tradicionais e abertamente favorável à constituição de uma elite ruralista nos atuais estados de Mato Grosso e Mato Grosso do Sul. A partir da redemocratização da sociedade brasileira, com o fim do regime de exceção (1964-1985) e a promulgação da Carta Constitucional de 1988, surge a possibilidade histórica dos coletivos reaverem parte de seus territórios. Entretanto, a ação do Estado continua cheia de percalços, incertezas e retrocessos, o que leva muitas vezes as próprias comunidades a duvidarem da efetividade das garantias legais.

Nesta linha de argumentação, analisar a trajetória da Família Bispo foi uma oportunidade de reflexão sobre importantes conceitos acionados nos processos de reconhecimento de direitos territoriais, como espaço, território, territorialização, territorialidade, comunidade e sociedade, além de (re)pensar a respeito dos recursos teórico-metodológicos implicados na pesquisa. Em face a esta particularidade, o presente artigo pode contribuir à realização de estudos desta natureza em outros contextos, nos quais pesquisadores se defrontam com problemas 
de semelhante natureza. Chama ainda a atenção para a necessidade de melhor conhecermos a própria (etno)história dos Bororo e Kayapó no norte do estado, tidos como 'extintos' ou inexistentes.

Outra contribuição importante se refere às possibilidades da realização de estudos sobre gênero em comunidades quilombolas e outras tradicionais. ○ caso da Família Bispo demonstra ser promissor à incorporação de contribuições do campo do parentesco e da organização social, além de elementos relativos às transformações em distintas situações históricas. Em recente publicação, Pereira \& Ximenes (2017) discutem como a expropriação das terras da comunidade Terena de Buriti, localizada nos municípios sul-mato-grossenses de Sidrolândia e Dois Irmãos do Buriti, conecta-se com processos de institucionalização de assimetrias de gênero. Referem-se ao processo em que homens assumiram posição central no cenário das relações políticas com o Estado e a sociedade nacional, de forma semelhante ao verificado na Família Bispo. No tempo presente, diante das transformações existentes na sociedade nacional brasileira, inclusive com atrizes sociais a assumir importantes posições em órgãos do Estado, mulheres de coletivos indígenas e quilombolas iniciaram um promissor movimento de reocupação dos espaços políticos, o que ocorre em distintos cenários etnográficos.

Por fim, se o 'largão' da terra 'voluta' (devoluta) se transformou em terra vendida, quer dizer, escriturada em cartório como propriedade privada de outrem, conforme formulação precisa de um dos nossos interlocutores, esta transformação envolveu violência e atropelos à lei. Aqui parece residir o 'preço de ser brasileiro', condição imposta pelas elites nacionais aos coletivos subalternizados no processo de construção da civilização brasileira, captada na letra da música "Peão", citada como epígrafe do artigo (Sater \& Teixeira, 1982). Para a comunidade da Família Bispo, a expropriação gradativa do território implicou o solapamento de suas formas de solidariedade grupal; intensificou tensões e comprometeu os mecanismos de resolução de conflitos. $\bigcirc$ processo administrativo de regularização fundiária pode estar paralisado, mas não esquecido, porque há o esforço de várias pessoas no sentido de retomá-lo. Afinal, pessoas como Joel conhecem as "trilhas, quilômetros, milhas que vêm e que vão pelo alto sertão" (Sater \& Teixeira, 1982).

\section{REFERÊNCIAS}

Aguilera Urquiza, A. H., \& Santos, L. S. (2017). Regularização fundiária de comunidades quilombolas em Mato Grosso do Sul/Brasil. Revista Brasileira de Políticas Públicas, 7(2), 231-247. doi: https://doi.org/10.5102/rbpp.v7i2.4753

Arruti, J. M. (2006). Mocambo: antropologia e história do processo de formação quilombola. Bauru: Edusc.

Baldo, A. C. S. (2015). Territorialidade quilombola e estratégias de resistência camponesa na agricultura familiar da Comunidade de Furnas do Dionísio/Jaraguari-MS (Dissertação de mestrado). Universidade Federal de Mato Grosso, Rondonópolis, MT, Brasil.

Bonfil Batalla, G. (1989). México profundo: una civilización negada. México: Editorial Grijalbo.

Eremites de Oliveira, J. (2012a). Sistema de assentamento e processo de territorialização entre os Terena da Terra Indígena Buriti, Mato Grosso do Sul, Brasil. Habitus, 9(1), 166-196.

Eremites de Oliveira, J. (2012b). A história indígena no Brasil e em Mato Grosso do Sul. Espaço Ameríndio, 6(2), 178-218. doi: https://doi.org/10.22456/1982-6524.31745

Eremites de Oliveira, J. (2013). O uso da arqueologia para a produção de laudos antropológicos sobre terras indígenas em Mato Grosso do Sul, Brasil. Tellus, 12(22), 27-48.

Eremites de Oliveira, J. (2015). (Re)aproximando os campos da antropologia social e da arqueologia no Brasil: etnoarqueologia em laudos antropológicos judiciais sobre terras indígenas em Mato Grosso do Sul. In J. Pacheco de Oliveira, F. Mura, \& A. B. Silva (Orgs.), Laudos antropológicos em perspectiva (pp. 234-261). Brasília: ABA.

Eremites de Oliveira, J. (2016). Conflitos pela posse de terras indígenas em Mato Grosso do Sul. Ciência e Cultura, 68(4), 4-5. doi: http://dx.doi.org/10.21800/231766602016000400002

Eremites de Oliveira, J. (2017a). Arqueología de contrato, colonialismo interno y pueblos indígenas en Brasil. In C. Gnecco \& A. S. Dias (Orgs.), Crítica de la razón arqueológica: arqueología de contrato y capitalismo (pp. 271-290). Bogotá: Instituto Colombiano de Antropología e Historia. 
Eremites de Oliveira, J. (2017b). Revisitando uma discussão sobre arqueologia, identidade étnica e direitos territoriais dos povos indígenas no Brasil. In J. B. Campos, M. H. S. G. Rodrigues \& P. P. A. Funari (Orgs.), A multivocalidade da arqueologia pública no Brasil: comunidades, práticas e direitos (pp. 32-76). Criciúma: Editora UNESC.

Eremites de Oliveira, J., \& Pereira, L. M. (2007). "Duas no pé e uma na bunda": da participação Terena na guerra entre o Paraguai e a Tríplice Aliança à luta pela ampliação de limites da Terra Indígena Buriti. Revista Eletrônica História em Reflexão, 1(2), 1-20.

Eremites de Oliveira, J., \& Pereira, L. M. (2009). Nande Ru Marangatu: laudo pericial sobre uma terra kaiowa na fronteira do Brasil com o Paraguai, em Mato Grosso do Sul. Dourados: Editora UFGD.

Eremites de Oliveira, J., \& Pereira, L. M. (2010). Reconhecimento de territórios indígenas e quilombolas em Mato Grosso do Sul: desafios para a antropologia social e a arqueologia em ambientes colonialistas. In R. L. S. Aguiar, J. Eremites de Oliveira \& L. M. Pereira (Orgs.), Arqueologia, etnologia e etnohistória em Iberoamérica: fronteiras, cosmologia e antropologia em aplicação (pp. 185-208). Dourados: Editora UFGD.

Eremites de Oliveira, J., \& Pereira, L. M. (2012). Terra Indígena Buriti: perícia antropológica, arqueológica e histórica sobre uma terra terena na serra de Macaraju, Mato Grosso do Sul. Dourados: Editora UFGD.

Fiabani, A. (2005). Mato, palhoça e pilão: o quilombo, da escravidão às comunidades remanescentes (1532-2004). São Paulo: Expressão Popular.

Haesbaert, R. (2006). O mito da desterritorialização: do "fim dos territórios" à multiterritorialidade. Rio de Janeiro: Bertrand Brasil.

Lima, E. C., \& J. Eremites de Oliveira (2017). Remoções forçadas de grupos indígenas no Brasil Republicano. Mediações, 22(2), 1323. doi: http://dx.doi.org/10.5433/2176-6665.2017v22n2p13

Lima, M. H. F. (2007). Etnografia do conflito na terra de remanescentes de quilombos Família Bispo no município de Sonora - MS. Nota técnica. Dourados: Ministério Público Federal. Recuperado de http://bibliotecadigital.mpf.mp.br/bdmpf/bitstream/ handle/11549/153787/familiabisporelatorioatualizadom. pdf? sequence $=1$ \&isAllowed $=y$

Lima, M. H. F., \& Guimarães, V. M. B. (2009, setembro). 0 administrativo, o jurídico e o político: três importantes processos da regularização fundiária das terras indígenas. In Anales de la VIII Reunión de Antropología del Mercosur Diversidad y Poder em América Latina, UNSAM, Buenos Aires.

Martins, J. S. (1997). Exclusão social e a nova desigualdade. São Paulo: Paulus.

Marx, K., \& Engels, F. (1986). A ideologia alemã (I - Feuerbach) (5. ed., J. C. Bruni \& M. A. Nogueira, Trad.). São Paulo: Hucitec.
Ministério Público Federal (MPF). (n.d.). Mapa Quilombolas. Recuperado de http://www.mpf.mp.br/ms/atuacao/mapaquilombolas

Mota, J. G. B. (2011). Territórios e territorialidades Guarani e Kaiowa: da territorialização precária na reserva indígena de Dourados à multiterritorialidade (Dissertação de mestrado). Universidade Federal da Grande Dourados, Dourados, MS, Brasil.

Nimuendajú, C. (2017). Mapa etno-histórico do Brasil e regiões adjacentes. Brasília: IPHAN/IBGE.

O'Dwyer, E. C. (Org.). (2002). Quilombos: identidade étnica e territorialidade. Rio de Janeiro: FGV.

O'Dwyer, E. C. (2008). Terras de quilombo no Brasil: direitos territoriais em construção. Ariús, 14(1-2), 9-16.

Oliveira, R. (2002). Euclides da Cunha, Os Sertões e a invenção de um Brasil profundo. Revista Brasileira de História, 22(44), 511-537. doi: https://doi.org/10.1590/S010201882002000200012

Pereira, L. M. (2003). O movimento étnico-social pela demarcação das terras guarani. Tellus, 3(4), 137-148.

Pereira, L. M. (2006). Modalidades de assentamento entre os Kaiowá atuais: o caso dos índios de corredor. Tellus, 6(10), 69-81.

Pereira, L. M. (2009). Os Terena de Buriti: formas organizacionais, territorialização e representação da identidade. Dourados: Editora da UFGD.

Pereira, L. M. (2010). Demarcação de terras kaiowá e guarani: ocupação tradicional, reordenamentos organizacionais e gestão territorial. Tellus, 10(18), 115-137.

Pereira, L. M. (2016). Os Kaiowá de MS: módulos organizacionais e humanização do espaço habitado. Dourados: Editora da UFGD.

Pereira, L. M. (2018). Ocupação colonial e formas de mobilidade entre os Guarani e Kaiowá na fronteira Brasil-Paraguai: a caminho do tekoha em busca do teko porã na região meridional da América do Latina. In A. H. Aguilera Urquiza (Org.), Fronteiras étnico-culturais: tráfico e migração de pessoas nas fronteiras de Mato Grosso do Sul (pp. 75-83). Campo Grande: Editora UFMS.

Pereira, L. M., \& Ximenes, L. G. (2017). O território terena: da expropriação e formação das reservas ao movimento das Retomadas. Revista Mediações, 21(2), 24-50. doi: http://dx.doi. org/10.5433/2176-6665.2017v22n2p24

Radcliffe-Brown, A. R. (1982). Introdução. In A. R. Radcliffe-Brown \& D. Ford (Orgs.), Sistemas políticos africanos de parentesco e casamento (pp. 11-101) (Marcos A. E. L. de Salvo Coimbra, Trad.). Lisboa: Calouste Gulbenkian. 
Santos, C. A. B. P. (2010). Fiéis descendentes: redes-irmandades na pós-abolição entre comunidades negras rurais sul-matogrossenses (Tese de doutorado). Universidade de Brasília, Brasília, DF, Brasil.

Santos, M. (2002). Por uma Geografia nova. São Paulo: Edusp.

Santos, M. (2004). Pensando o espaço do homem. São Paulo: Edusp.

Saruwatari, G. K. (2014). Comunidade Quilombola Dezidério Felippe de Oliveira: tradição, política e religião entre os "Negros da Picadinha" (Dissertação de mestrado). Universidade Federal da Grande Dourados, Dourados, MS, Brasil.

Sater, A., \& Teixeira, R. (1982). Peão [Gravada por A. Sater]. On Doma [LP]. Recuperado de https://musicabrasilis.org.br/ compositores/almir-sater

Seyferth, G. (2001). Campesinato e o Estado no Brasil. Mana, 17(2), 395-417. doi: http://dx.doi.org/10.1590/S010493132011000200006

Soares, L. E. (1981). Campesinato: ideologia e política. Rio de Janeiro: Zahar.

Souza, O. C. N., S. Becker, \& J. Eremites de Oliveira. (2012). Negações para a produção de perícia antropológica em processos criminais no Tribunal de Justiça de Mato Grosso do Sul (TJMS), Brasil. In A. J. G. Brito, S. Becker \&J. Eremites de Oliveira (Orgs.), Estudos de Antropologia Jurídica na América Latina Indigena (pp. 141-170). Curitiba: CRV.
Strathern, M. (1988). The gender of the gift: problems with women and problems with society in Melanesia. Berkeley: University of California Press.

Valencio, N. (2009). Da 'área de risco' ao abrigo temporário: uma análise dos conflitos subjacentes a uma territorialidade precária. In N. Valencio, M. Siena, V. Marchezini \& J. C. Gonçalves (Orgs.), Sociologia dos desastres - construção, interfaces e perspectivas no Brasil (pp. 34-47). São Carlos: RiMa Editora.

Weber, M. (1969). Economia y sociedad: esbozo de sociologia comprensiva (José Medina Echevarría et al., Trad.). México: Fondo de Cultura Económica.

Weber, M. (1973). Comunidade e sociedade como estruturas de socialização. In F. Fernandes (Org.), Comunidade e sociedade: leituras sobre problemas conceituais, metodológicos e de aplicação (pp. 140-143). São Paulo: Editora Nacional/Edusp.

Woortmann, K. (1990). "Com parente não se neguceia": o campesinato como ordem moral. Anuário Antropológico, 12(1), 11-73.

\section{CONTRIBUIÇÃO DOS AUTORES}

J. Eremites de Oliveira contribuiu com conceituação, análise formal, investigação, metodologia, administração de projeto, recursos e escrita (rascunho original, revisão e edição); e L. M. Pereira com conceituação, análise formal, investigação, metodologia, recursos, validação e escrita (rascunho original, revisão e edição). 